Dragana Drobnjak*

UDK 811.133.1'373.7

Snežana Gudurić

$811.163 .41 ' 373.7$

Filozofski fakultet

Univerzitet u Novom Sadu

DOI: $10.19090 /$ gff.2017.1.199-218

Originalni naučni rad

\title{
SRCE U FRANCUSKOJ I SRPSKOJ FRAZEOLOGIJI**
}

Predmet rada čine francuski i srpski frazemi sa komponentama fr. cœur / srp. srce. Cilj rada je da putem semantičke i kontrastivne analize utvrdimo motivisanost odabranih frazema, te da ih shodno njihovoj pozadinskoj slici, prateći leksikografski model 'tehnike grozdova' Dobrovoljskog, razvrstamo u konceptualna polja i ustanovimo (ne)podudarnost njihove leksičke i semantičke strukture. Korpus za ovo istraživanje ekscerpiran je iz francuskih i srpskih opštih i frazeoloških rečnika, dnevnih i nedeljnih novina, elektronskih medija.

Ključne reči: srce, frazem, francuski, srpski.

\section{UVOD}

Bogata i tematski raznovrsna frazeologija svojstvena je svakom jeziku (Moon, 1998), budući da dotiče raznolike oblasti čovekovog postojanja i delanja. Somatska frazeologija, kao neizostavan deo frazeologije utemeljen na univerzalnoj antropocentričnoj tendenciji, obiluje metaforičkim i metonimijskim modelima koji su proistekli iz poimanja čoveka kao vaskolikog merila. Telo je postalo heuristički model za razumevanje kosmosa, samim tim što je slika sveta koji okružuje čoveka iznedrena iz misaonih postupaka istovetnih postupcima kojima se opaža sopstveno telo i njegov položaj u tom svetu (Radenković, 1991: 193).

Prema teorijskim postavkama Giroa (Guiraud, 1975: 8) telo je sedište svih čovekovih saznanja i osećaja samim tim što su psihičke funkcije utemeljene i imenovane na osnovu slika koje ono odražava. Shodno tome, nevidljiva psiha se u tradicionalnoj psihologiji poima kao odraz vidljivog tela.

Karakter somatizama je univerzalan i izvire iz tradicionalne simbolike delova tela, gestova, mimike, narodnog verovanja, tradicije i praznoverja (MrševićRadović, 1987). Dok su u spoljašnjoj somatskoj frazeologiji podjednako zastupljeni svi vidljivi delovi čovekovog tela (npr. glava, lice, oči, uši, ruke, noge, prsti), u unutrašnjoj somatskoj frazeologiji u mnogim lingvokulturološkim zajednicama

\footnotetext{
*dashayuyu@yahoo.fr

** Rad je urađen u okviru projekta MNTR br. 178002 Jezici i kulture u vremenu i prostoru.
} 
znatno preovladava somatizam srce u odnosu na druge unutrašnje organe (npr. stomak, želudac, bubrezi, živci) ili telesne tečnosti (npr. krv, sluz, znoj, suze).

U ovom radu pažnju smo usmerile ka francuskoj i srpskoj somatskoj frazeologiji sa željom da utvrdimo obojenost leksema fr. cœur / srp. srce i koncepte koje one izražavaju. Jezičkim realizacijama u našem korpusu metodom semantičke dekompozicije pridružile smo odgovarajuće deskriptore, te ih shodno tome svrstale u odgovarajuća konceptualna polja. Korpus za ovo istraživanje ekscerpiran je iz brojnih izvora na francuskom i srpskom jeziku: opštih i frazeoloških rečnika, dnevnih i nedeljnih novina, elektronskih medija, bez pretenzije da u analizu uvrstimo sve postojeće jezičke realizacije sa posmatranim komponentama. Odabrane jezičke realizacije pripadaju standardnom i familijarnom francuskom i srpskom jeziku, potvrđene su u savremenoj jezičkoj praksi, a njihova učestalost je bio presudan kriterijum u priključivanju građi.

\section{SRCE I KONCEPTUALNA POLJA}

Od pamtiveka se srce smatra jednim od najvažnijih, ako ne i najvitalnijim organom. Razna mitska i magična verovanja izvorište pronalaze u ovom delu ljudskog i životinjskog tela, samim tim što se srce oduvek poimalo kao središte raznolikih emocija, ljubavi i čestitosti, plemenitosti i samilosti, odvažnosti i srčanosti, besa i nemilosrdnosti, bezosećajnosti i grubosti.

Dok su stari Egipćani verovali da je srce središte duševnog života, prevashodno mišljenja, većina grčkih filozofa poimala je srce kao utočište volje, osećanja i mišljenja. Tako prema Platonu duša obitava u srcu, glavi i stomaku, a prema Aristotelovom promišljanju duša se nalazi isključivo u srcu, dok mozak ima nebitan značaj (Guthrie, 1962). Prema Apresjanu (Апресјан II, 1995) intelektualna delatnost se lokalizuje u glavi, pameti, umu (npr. pretpostavljati, shvatiti, saznavati), govorna u ustima, na jeziku i drugim govornim organima (npr. saopštiti, savetovati, hvaliti, rugati se), dok su u srcu i duši smeštene okulturene želje povezane sa duhovnim potrebama i emocijama (npr. radovati se, voleti, diviti se, mrzeti).

Srce, dakle, odiše izobiljem simbolike, budući da se u naivnoj slici sveta ono poistovećuje sa čovekovim unutrašnjim bićem, onim najtananijim i najskrivenijim duhovnim i emotivnim kutkom. Često uminu i granice između srca i duše, o čemu svedoče frazemi u kojima se u okviru istih kognitivnih jedinica pojavljuju i srce i $d u \check{s} a$ :

fr. son cœur, son âme brûle (pour quelqu'un, quelque chose) / srp. srce, duša mu gori, izgara (za nekim, nečim) 
fr. cela vient de mon cour, âme / srp. to mi dolazi iz srca, duše

fr. être gravé dans le cour, l'âme / srp. urezati se u srce, dušu

Shodno definiciji iz RMS (1263-1264) srce odlikuje nekoliko značenja: 1. a) centralni mišićast organ u grudima koji reguliše krvotok u telu; b) mesto na levoj strani grudi pod kojim se taj organ nalazi. 2. (obično u izrazima) a) narav, priroda, karakter; b) unutrašnji čovekov svet, duša; v) osećajni život čovekov; d) u prisnom obraćanju, obično uz reč „moje”, u značenju: draga moja, dragi moj. 3. fig. a) središnje mesto (države, pokrajine, oblasti), središte, centar; b) sredina kakvog ploda, cveta i sl., jezgro; v) unutrašnjost čega. 4. nar. želudac, stomak. 5. kao sastavni deo nekih botaničkih naziva.

Značenja francuske lekseme cour u relevantnim francuskim rečnicima (TLF, Le Petit Robert) odgovaraju navedenim značenjima u srpskom jeziku, te ih ovde nećemo posebno navoditi.

$\mathrm{Na}$ međujezičkom planu, dakle, uočavamo istovetnost polisemičnih struktura posmatranih leksema. Našim istraživanjem utvrdićemo da li se u francuskoj i srpskoj lingvokulturološkoj zajednici navedeni semantički sadržaji jednako konceptualizuju ili odišu raznolikim poimanjem stvarnosti.

Frazem predstavlja spoj dve ili više reči (pri čemu uslov ne predstavlja punoznačnost barem jedne od njih) koji odlikuje čvrsta struktura, bez obzira na njenu (ne)idiomatičnost (Burger, 1982). Kod globalnih frazema uočljiva je tesna uzajamna povezanost komponenata od kojih se niti jedna ne može dodati ili izostaviti, niti se njihov redosled može promeniti. Kod komponentnih frazema deo komponenti je figurativno obojen, a deo zadržava primarno značenje. Tako frazem avoir le cour au bord des lèvres nosi značenje „osećati mučninu”. Ukoliko se umesto au bord upotrebi drugi lokalistički predlog, sur, nastaje frazem sa drugačijim značenjem ,biti iskren”. Upotreba različitih predloga osim formalnih razlika među frazemima otkriva i drugačije poimanje značenjskih odnosa između komponenata. Isto tako, frazem imati na srcu upućuje na postojanje teskobe ili problema, dok frazem imati u srcu koji se razlikuje u samo jednom segmentu ističe da nam je neka osoba, predmet ili pojam veoma drag. Dok se u prvom primeru nagoveštava prisustvo nekog tereta koji pritiska srce, $u$ drugom se srce poima kao posuda koju punimo sadržinom, odnosno emocijama.

$\mathrm{S}$ druge strane, u komponentnom frazemu parler à cœur ouvert (,govoriti iskreno") glagol parler zadržava osnovno značenje, nosilac je semantike celokupnog frazema i može se zameniti drugim glagolima (npr. agir, raconter). Segment à cour ouvert prolazi kroz semantičku transpoziciju budući da ga nije moguće doslovno prevesti, te preuzima značenje priloga 'iskreno'. U srpskom jeziku takođe uočavamo komponentne frazeme: biti širokog/velikog srca, iz dna 
srca/iz sveg srca koji mogu da stoje uz razne glagole (npr. voleti, mrzeti). Ukoliko se, međutim, upotrebljavaju bez glagola, posmatramo ih kao globalne frazeme.

U kognitivnoj lingvistici frazemi predstavljaju psiholingvističke jedinice unutar 'mentalnog leksikona'. Ovaj leksikon istkan je od mreže pojmovnih jedinica razvrstanih u jedno ili više konceptualnih polja koja su omeđena prema izvanjezičkim kriterijumima, odnosno utemeljena su na svakolikom čovekovom znanju o svetu. Konceptualno-semantičko umreženje frazema izvire iz metode semantičke dekompozicije tako što se frazemima pridružuju odgovarajući deskriptori, tačnije relevantna svojstva zasnovana na odnosima sličnosti. Dobrovoljski (prema Zybatov 1997: 582) predlaže 'tehniku grozdova' u okviru koje frazeme istog grozda povezuje semantička sličnost na intuitivnom nivou. Kontekst često utiče na pridruživanje deskriptora frazemima, te pojedine višeznačenjske frazeme samim tim može da krasi više deskriptora. Osim toga, samim tim što su frazemi unutar jednog grozda združeni u značenjsku celinu usled istovetnog relevantnog obeležja, oni ne moraju obavezno da dele isti deskriptor.

Prateći ovakav leksikografski postupak, frazeme iz našeg korpusa smo prema njihovoj pozadinskoj slici grupisale u pet konceptualnih polja: 1) 'čovekove osobine', 2) 'čovekova stanja', 3) 'čovekovo ponašanje i odnos prema drugim ljudima', 4) 'način čovekovog delanja', 5) 'središte'.

$\mathrm{U}$ našem istraživanju pod potpunom ekvivalencijom frazema $u$ dva jezika podrazumevamo istovetnost morfosintaksičke strukture, frazeološkog i doslovnog značenja, konotativnosti i pozadinske slike. Frazeme istog ili sličnog značenja, ali neistovetne leksičke strukture smatramo korespondentima, ne i ekvivalentima, te ih posebno navodimo. Kod francuskih primera za koje ne pronalazimo ekvivalent $\mathrm{u}$ srpskom jeziku u zagradi dajemo doslovno značenje komponenata frazema, a ne frazeološko značenje. Doslovno značenje frazeoloških komponenti veoma je važan kriterijum budući da odnos doslovnog i frazeološkog značenja ukazuje na (ne)prozirnost motivacije i određuje stepen idiomatičnosti.

1. Konceptualno polje 'čovekove osobine'

Prvu podgrupu čine frazemi koji upućuju na karakterizaciju čoveka, odnosno na njegove: a) fizičke i b) karakterne odlike:

a) fizički izgled:

- 'veoma sladak, slatka', 'veoma šarmantan,-na':

fr. être beau, belle, joli, jolie comme un cour (*biti lep,-a kao srce) / srp. fr. être mignon,-ne comme un cœur (*biti sladak, slatka kao srce) / srp. -

b) karakterne odlike: 
Svi frazemi u ovoj skupini izražavaju trajne osobine. Od poželjnih karakternih odlika uočavamo sledeće:

- 'dobrota', 'plemenitost', '(sa)osećajnost':

fr. avoir un cour en, d'or / srp. imati zlatno srce

fr. avoir un grand cour / srp. imati veliko srce

fr. avoir bon cour / srp. imati dobro srce

fr. avoir le cour sur la main 1 / srp. imati srce na dlanu

fr. être un vrai cour / srp. biti pravo srce

fr. avoir le cour à la bonne place ${ }^{2}$ (*imati srce na dobrom mestu) / srp. -

fr. être un cour sur deux pattes (*biti srce na dve šape) / srp. -

fr. être tout cour (*biti sav srce) / srp. -

fr. être un homme de cour (*biti čovek od srca) / srp. -

fr. - / srp. imati meko srce

fr. - / srp. imati široko srce

fr. - / srp. biti dobrog srca

fr. - / srp. biti srce od čoveka

- 'dobrota', 'milosrđe', 'čistota duše', 'bezgrešnost':

fr. avoir un cour pur / srp. imati čisto srce

fr. - / srp. biti čistog srca

- 'nežnost':

fr. être tendre comme un cour (*biti nežan kao srce) / srp. -

- 'ljubaznost':

fr. être gentil,-le comme un cour (*biti ljubazan,-na kao srce) / srp. -

- ' iskrenost':

fr. avoir le cour sur les lèvres ${ }^{3}$ (*imati srce na usnama) / srp. -

\footnotetext{
${ }^{1}$ U pozadinskoj slici uočavamo dobru osobu čija su osećanja izložena na dlanu, te je spremna da ih podari nekome. Pružena ruka sama po sebi je izuzetno snažan simbol solidarnosti i plemenitosti.

${ }^{2}$ Ovaj frazem je nastao kalkiranjem engleskog frazema to have one's heart in the right place.

${ }^{3}$ Frazem ima još jedno značenje, ,imati mučninu”, ,imati želju za povraćanjem”, te smo ga svrstale i u naredno konceptualno polje među frazeme koji upućuju na čovekovo fiziološko stanje.
} 
- $\quad$ 'spontanost', 'naivnost', ‘čistota duše', 'radost':

fr. avoir un cour d'enfant (*imati srce dečije) / srp. -

- 'neustrašivost':

fr. avoir du cœeur (*imati srca) / srp. -

fr. avoir du coeur au ventre ${ }^{4}$ (*imati srce u stomaku) / srp. -

Posebno su zanimljivi frazemi u kojima se karakterizacija čoveka ostvaruje poređenjem sa životinjama. U frazemima fr. avoir un cœur de lion ${ }^{5} / \mathrm{srp}$. imati lavlje srce uočava se metonimijski odnos budući da se srce lava koji je oličenje neustrašivosti poima kao sušta hrabrost koja ispunjava njegovo srce. Tako ovakav metonimijski prenos postaje temelj pojmovne metafore u okviru koje karakteristika lava (hrabrost koja se nalazi u srcu) izrasta u izvorni domen, a odvažan čovek ciljni domen na koji se preslikava ova osobina.

U našem korpusu pronalazimo i frazeme koji iskazuju pojedine nepoželjne karakterne osobine. Najprisutniji u ovoj skupini jesu frazemi kojima se ističe odsustvo osetljivosti, duševnosti, nedobrote:

$$
\text { - ' 'neosetljivost', 'bezdušnost': }
$$

fr. avoir un cour dur, endurci / srp. imati tvrdo srce

fr. avoir un cour de glace, avoir un cour glacé / srp. imati ledeno srce

fr. être sans cœur / srp. biti bez srca ${ }^{6}$

fr. avoir un cour froid / srp. imati hladno srce

fr. avoir le cour sec (*imati srce suvo) / srp. -

fr. manquer de cour (*nedostajati srca) / srp. -

fr. - / srp. biti tvrdog srca

$$
\text { - 'zloba': }
$$

fr. avoir un mauvais cœur / srp. imati zlo srce

fr. - / biti zlog srca

\footnotetext{
${ }^{4}$ U srednjem veku, leksema ventre je pored značenja ,trbuh, stomak” upućivala kako na „grudni koš” tako i na „unutrašnjost glave”.

${ }^{5}$ Frazem je popularizovan pod uticajem francuskih istoričara koji su ovaj nadimak nadenuli engleskom kralju Ričardu I zbog njegove neustrašivosti.

${ }^{6} \mathrm{U}$ pojedinim frazemima u našem korpusu mogući su varijantni oblici kada se lekseme fr. cour / srp. srce kao komponente mogu zameniti leksemama fr. âme / srp. duša. Nećemo navoditi ovu varijantnost budući da to nije predmet našeg istraživanja.
} 
U brojnim frazemima, prevashodno francuskim, srce se poistovećuje sa kakvom tvrdom neprobojnom materijom:

fr. avoir un cour de pierre / srp. imati kameno srce, srce od kamena

fr. avoir un coeur d'acier / srp. imati čelično srce, srce od čelika

fr. avoir un coeur de marbre (*imati srce od mermera) / srp. -

fr. avoir un cœur de granit (*imati srce od granita) / srp. -

fr. avoir un cour de bronze (*imati srce od bronze) / srp. -

fr. avoir un cour d'airain (*imati srce od bronze) / srp. -

fr. avoir un cour de roche (*imati srce od stene) / srp. -

fr. avoir un cour de fer (*imati srce od gvožđa) / srp. -

fr. - / srp. biti kamenog srca

I u ovoj skupini uočavamo poistovećivanje čoveka sa određenim životinjama ili biljkama:

- 'izrazita plašljivost', 'kukavičluk':

fr. avoir un cour de lièvre / srp. imati zečje srce

- 'velika okrutnost':

fr. avoir un cour de tigre (*imati srce tigra) / srp. -

- ' 'emotivna nestalnost', 'biti zaljubljive prirode':

fr. avoir un cæeur d'artichaut ${ }^{7}$ (*imati srce artičoke) / srp. -

2. Konceptualno polje 'čovekova stanja'

Konceptualnom polju 'čovekova stanja' pridružile smo sadržaje koji se odnose na: a) fiziološka i b) psihička stanja:

a) 'čovekova fiziološka stanja':

Nije neobično da u ovoj skupini pronalazimo isključivo francuske frazeme, budući da je do sedamnaestog veka leksema cœur imala i značenje „stomak"8. Otuda i semantika ovih frazema.

Skoro svi frazemi ukazuju na kakvo trenutno neprijatno fizičko stanje:

\footnotetext{
${ }^{7}$ Srce ovde označava središnji deo biljke sa kojeg se odvajaju brojni listovi, po jedan za svaku prisutnu osobu. Otuda metaforičko upućivanje na osobu koja nudi malo ljubavi svakome ko joj privuče pažnju. Frazem je nastao krajem devetnaestog veka i proistekao je iz poslovične izreke cour d'artichaut, une feuille pour tout le monde (*srce artičoke, jedan list za svakog).

${ }^{8} \mathrm{O}$ ovom značenju u srpskom jeziku biće govora u daljem tekstu.
} 
- 'imati mučninu', ‘imati želju za povraćanjem':

fr. avoir le cour soulevé (*imati srce ${ }^{9}$ podignuto) / srp. -

fr. avoir mal au coeur (*imati bol u srcu) / srp. -

fr. avoir le cour au bord des lèvres (*imati srce na krajičku usana) / srp. -

fr. avoir le cour sur les lèvres (*imati srce na usnama) / srp. -

fr. avoir le cour barbouillé (*imati srce ubrljano) / srp. -

fr. avoir le cœur noyé (*imati srce utopljeno) / srp. -

fr. avoir le cour à l'envers (*imati srce naopačke) / srp. -

fr. se sentir le cœur retourné (*osećati sebi srce okrenuto) / srp. -

- $\quad$ 'izazivati gađenje', 'zgaditi':

fr. retourner le cour à quelqu'un (*preokrenuti srce nekome) / srp. -

fr. lever le cour (*dići srce) / srp. -

fr. soulever le cour (*podići srce) / srp. -

fr. faire mal au cœur ${ }^{10}$ (*praviti bol u srcu) / srp. -

- ' osećati bol u grudima':

fr. avoir une pointe au cœur (*imati bodlju u srcu) / srp. -

Svega jedan frazem nosi pozitivnu konotaciju:

- ' 'biti otporan na ono što izaziva gađenje':

fr. avoir le cour bien accroché ${ }^{11}$ (*imati srce dobro zakačeno) / srp. -

b) 'čovekova psihička ${ }^{12}$ stanja':

Određeni broj francuskih i srpskih frazema opisuje čovekove emocije koje ne mogu direktno da se percipiraju, nego se poimaju zahvaljujući prototipičnim

\footnotetext{
${ }^{9} \mathrm{U}$ doslovnom prevodu frazema u ovoj skupini umesto srca može ravnopravno da stoji i stomak.

${ }^{10}$ Navedeni frazem ima i značenje ,izaz(i)vati tugu” i ,izaz(i)vati saosećanje”, te smo ga svrstale i u okvire konceptualnog polja 'čovekovo ponašanje i odnos prema drugim ljudima'.

${ }^{11}$ Odnosi se i na gnušanje u metaforičkom smislu.

12 Pod psihičkim stanjem podrazumevamo i bazične, biološki uslovljene emocije, i sekundarne, okulturene emocije.

U bazične emocije svrstavaju se sreća, ljubav, radost, ljutnja, bes, tuga, strah, iznenađenje i interesovanje, jer za njih postoje odgovarajuće facijalne ekspresije. Sekundarne emocije, kao što su nada, očajanje, dosada, ljubomora, neugoda, motivisane su intelektualnom ocenom situacije kao željene ili neželjene za subjekta i svojstvene su isključivo čoveku.
} 
spoljašnjim manifestacijama i u jeziku se konceptualizuju kroz metaforičke i metonimijske modele.

U frazemima koji slede pronalazimo veoma produktivnu pojmovnu metaforu u kojoj se srce konceptualizuje kao s(r)edište emocija, kao prostor u kome se nalazi čovekovo unutrašnje biće, njegova suština.

Većina frazema u ovoj podgrupi ukazuje na čovekovo nelagodno psihičko stanje, neraspoloženje i neprijatna osećanja. Najbrojniji među njima su frazemi u kojima se (golema) tuga, povređenost, očaj, veliki duševni bol oličavaju kao bol srca uprkos medicinskoj činjenici da bol srčanog mišića fiziološki nije moguć:

fr. avoir mal au cour / srp. boli srce nekoga

fr. son cour se serre / srp. steže mu se srce

fr. avoir le cour qui saigne / srp. imati srce koje krvari

fr. son cour se déchire / srp. srce mu se cepa, kida, para

fr. peser sur le cour / srp. biti teško na srcu nekome

fr. avoir le cour serré (*imati srce stegnuto) / srp. -

fr. avoir le cour gros (*imati srce veliko) / srp. -

fr. avoir le cour lourd (*imati srce teško) / srp. -

fr. en avoir gros sur le cour ${ }^{13}$ (*imati veliko na srcu) / srp. -

fr. en avoir lourd sur le cour (*imati teško na srcu) / srp. -

fr. - / srp. imati na srcu ranu

Pored tuge, u srcu mogu da se nastane i druge emocije:

- $\quad$ 'teret na duši':

fr. avoir quelque chose sur le cour / srp. imati nešto na srcu

fr. avoir un poids sur le cour / srp. imati teret na srcu

- ' kratkotrajan i bolan osećaj usled kakve emocije':

fr. avoir un pincement au cour (*imati štipanje u srcu) / srp. -

$$
\text { - 'bes': }
$$

fr. avoir la rage au cour / srp. imati bes u srcu

fr. en avoir gros sur le cœur (*imati veliko na srcu) / srp. -

- 'bezvoljnost':

fr. n'avoir le cour à rien (*nemati srce za ništa) / srp. -

\footnotetext{
${ }^{13}$ Frazem ima i sekundarno značenje „osećati bes” i sa tim značenjem smo ga uvrstile još jednom $\mathrm{u}$ istu ovu grupu, ali smo mu pridružile drugi deskriptor.
} 
- $\quad$ 'teško prihvatiti nešto':

fr. rester sur le coeur (*ostati na srcu) / srp. -

- $\quad$ 'pritajiti bol', 'skupiti snagu':

fr. - / srp. stegnuti srce

- $\quad$ 'ražalostiti se', 'ozbiljno nešto shvatiti', 'lično shvatiti':

fr. - / srp. uzeti, uzimati $k$ srcu

fr. - / srp. primati nešto $k$ srcu

- 'osetiti olakšanje', 'osloboditi se velike brige, problema, tegobe':

fr. - / srp. teret je nekome pao sa srca

fr. - / srp. kamen je nekome pao sa srca

- $\quad$ 'veliki strah':

fr. avoir un coeur transi de crainte (*imati srce smrznuto od straha) / srp. -

fr. - / srp. nekome je srce stalo od straha

fr. - / srp. nekome se ledi srce od straha

fr. - / srp. nekome srce silazi u pete

$\mathrm{U}$ poslednjem frazemu uočavamo dve metonimije, najpre srce koje se poistovećuje sa osobinama koje se nalaze u njemu (kao i kod drugih frazema), potom pete koje usled metonimijskog prenosa ukazuju na bežanje kao uobičajenu reakciju izazvanu strahom.

Srce se u francuskoj i srpskoj frazeologiji poima i kao sedište ljubavi, nežnosti, privrženosti, radosti:

$$
\text { - 'osećati ljubav prema nekome': }
$$

fr. avoir quelqu'un dans son cœur / srp. imati nekoga u srcu

fr. porter quelqu'un dans son cœur / srp. nositi nekoga u srcu

- $\quad$ 'biti nekome drag', 'biti predmet nečijih misli':

fr. être dans le cœur de quelqu'un / srp. biti u nečijem srcu

fr. - / srp. ležati kome na srcu

fr. - / srp. biti nekome na srcu

- 'biti srećan', 'biti radostan', 'biti blažen zbog ispunjenja neke želje, očekivanja': 
fr. avoir le cour léger (*imati srce lagano) / srp. -

fr. - / srp. puno je srce nekome

fr. - / srp. srce (za)igra nekome

fr. - / srp. srce raste nekome

fr. - / srp. milo je nekome oko srca

fr. - / srp. srce mu je na mestu

fr. - / srp. biti toplo oko srca

- ' biti oduševljen nekim/nečim':

fr. avoir un coup de cœur (*imati udarac srca) / srp. -

Pojedini frazemi nisu sami po sebi pozitivno ili negativno konotirani, već su kontekstualno obojeni. U narednim frazemima određeno psihičko stanje prate i svojevrsne fizičke manifestacije:

- ' 'osećaj neuobičajenog lupanja srca usled snažne emocije (zaljubljenosti, straha, besa, strepnje)':

fr. avoir le cœur qui bat (fort, vite) / srp. imati srce koje lupa (snažno, brzo)

fr. avoir le cour qui bat la chamade ${ }^{14}$ (*imati srce koje dobuje) / srp. -

fr. cou qui bat à tout rompre (*srce koje lupa da sve slomi) / srp. -

fr. - / srp. iskočiće srce nekome

fr. - / srp. nekome srce udara, tuče kao ludo

fr. - / srp. nekome je srce zadrhtalo

Pojedini frazemi otkrivaju raznolika osećanja usled gubitka ili neimanja ljubavi:

- 'osećati veliku tugu nakon rastanka ili gubitka voljenog bića':

fr. avoir le cœur brisé / srp. imati slomljeno srce

fr. avoir le cour en miettes (*imati srce u mrvicama) / srp. -

- ' 'biti bez ljubavi':

fr. - / srp. nekome je hladno oko srca

3. Konceptualno polje 'čovekovo ponašanje i odnos prema drugim ljudima'

\footnotetext{
${ }^{14}$ Poreklo ovog izraza pronalazimo u italijanskoj reči ciamada („vika”, ,poziv”). Ona je upućivala na vojnu proceduru dobovanja kojim se neprijateljskoj strani poručivalo da se traži kratak prekid borbe ili predaja. La chamade je nekada označavala vrstu oružja koje je pravilo veliku buku.
} 
Semantika frazema oličenih u ovoj skupini ilustruje čovekovo ponašanje, kao i odnos prema ljudima u njegovom okruženju. U narednim frazemima prisustvo drugih osoba je moguće, ali nije obavezno:

- ' 'raditi nešto predano sa uživanjem, poletom':

fr. s'en donner à coeur joie (*dati se srcem radost) / srp. -

fr. avoir le cour à l'ouvrage, au métier (*imati srce u poslu) / srp. -

fr. y mettre du cœur (*u nešto staviti srca) / srp. -

fr. mettre tout son cour (*staviti celo svoje srce) / srp. -

fr. prendre quelque chose à cour (*uzeti nešto na srce) / srp. -

fr. - / srp. uneti srce u nešto

- $\quad$ 'želeti jako nešto', 'držati do nečega', 'biti veoma zainteresovan za nešto':

fr. avoir à coeur (*imati na srcu) / srp. -

fr. tenir à cœur (*držati na srcu) / srp. -

fr. prendre à cour (*uzeti na srce) / srp. -

- 'ne ograničavati svoje želje':

fr. - / srp. pustiti srcu na volju

- $\quad$ 'ne obeshrabriti se pred teškoćama', 'zadovoljiti se onim što se ima', 'prihvatiti kompromis':

fr. faire contre mauvaise fortune bon cœur (*činiti protiv loše sreće dobro srce) / srp. -

- ' 'smejati se iskreno bez podrugivanja':

fr. rire de bon cour (*smejati se dobrim srcem) / srp. -

- ' biti načisto u vezi sa nečim':

fr. en avoir le cœur net (* zbog toga imati srce čisto) / srp. -

- $\quad$ 'gristi se', 'nervirati se':

fr. se ronger le cœur (*sebi jesti srce) / srp. -

- ' 'lišiti se večere', 'ostati bez večere':

fr. dîner par cœur ${ }^{15}$ (*večerati na srce) / srp. -

${ }^{15}$ Ovaj šaljivi frazem se prvobitno odnosio na osobu koja je mnogo pričala i recitovala, te samim tim nije stizala da večera. 
Za razliku od prethodno navedenih, u ovim frazemima uočavamo neophodnost prisustva drugih osoba. Pozitivnu konotaciju nalazimo u sledećim slučajevima:

$$
\text { - } \quad \text { 'poveriti se nekome', 'izjadati se': }
$$

fr. parler à cour ouvert / srp. pričati otvorenog srca

fr. ouvrir son cour à quelqu'un ${ }^{16} / \mathrm{srp}$. otvoriti svoje srce nekome

fr. découvrir son cœur / srp. otkriti svoje srce

fr. décharger son cour / srp. rasteretiti srce

fr. vider son cour / srp. isprazniti srce

fr. épancher son coeur (*izliti svoje srce) / srp. -

fr. parler d'abondance de cœur (* pričati obilno iz srca) / srp. -

- $\quad$ 'biti podrška nekome':

fr. être de (tout) coeur avec quelqu'un / srp. biti sa nekim svim srcem

- 'pružiti utehu nekome':

fr. réchauffer le cour de quelqu'un / srp. ugrejati srce nekome

fr. faire chaud au cour (*praviti toplo u srcu) / srp. -

fr. mettre du baume sur le cour (*staviti melema na srce) / srp. -

$$
\text { - 'ohrabriti nekoga': }
$$

fr. (re)donner du coeur au ventre (*(ponovo) dati srca u stomak) / srp. fr. mettre du cour au ventre (*staviti srca u stomak) / srp. -

- 'razveseliti nekoga':

fr. dilater le cœur de quelqu'un (*(ra)širiti srce nečije) / srp. -

- $\quad$ 'ganuti nekoga':

fr. aller droit au cœur de quelqu'un / srp. ići pravo u nečije srce

fr. toucher le cour de quelqu'un / srp. dotaći nečije srce

- 'raznežiti nekoga', 'izazvati nečiju samilost', 'učiniti da neko popusti':

fr. attendrir le cour de quelqu'un / srp. raznežiti nečije srce

fr. amollir le cœur de quelqu'un / srp. smekšati, razmekšati nečije srce

\footnotetext{
${ }^{16}$ Frazem nosi i značenje „dozvoliti nekome/nečemu da uđe u naš život”, te smo ga sa ovim značenjem još jednom svrstale $u$ isto ovo konceptualno polje sa drugačijim deskriptorom.
} 
- ' 'zagrliti nekoga':

fr. serrer sur son cœur (*stegnuti na svoje srce) / srp. -

fr. presser sur son cour (*pritisnuti na svoje srce) / srp. -

- ' $\quad$ poznavati nekoga veoma dobro':

fr. connaître quelqu'un par cœur (*poznavati nekoga na srce) / srp. -

- ' 'biti istih osećanja, misli, želja':

fr. - / srp. biti brat po srcu

- 'ne moći iz sažaljenja (reći, uraditi)':

fr. - / srp. nemati srca

- $\quad$ 'osećati sažaljenje prema nekome':

fr. avoir mal au coeur (*imati bol u srcu) / srp. -

- $\quad$ 'osloboditi nekoga bola, muke':

fr. arracher (à quelqu'un) une épine du cœur (*iščupati (nekome) trn iz srca) / srp. -

U ovo konceptualno polje uvrstile smo i frazeme u kojima pozadinsku sliku čini ljubav:

- ' $\quad$ predati se emotivno nekome', 'zavoleti nekoga':

fr. donner son cour à quelqu'un / srp. dati nekome srce

fr. offrir son cœur à quelqu'un / srp. pokloniti nekome srce

- 'dozvoliti nekome/nečemu da uđe u nečiji život':

fr. ouvrir son cour à quelqu'un/ à quelque chose / srp. otvoriti svoje srce za nekoga/nešto

- $\quad$ 'osvojiti nečiju ljubav':

fr. gagner le cœur de quelqu'un / srp. osvojiti nečije srce

fr. voler le cour de quelqu'un / srp. ukrasti nečije srce

- $\quad$ 'mnogo se voleti':

fr. n'être qu'un cœur et qu'une âme / srp. biti jedno srce i duša

$$
\text { - 'mnogo voleti nekoga/nešto': }
$$

fr. - / srp. srce vuče nekoga ka nekome/nečemu 
fr. - / srp. srcu, za srce prirasti

- $\quad$ 'ljubavna čežnja':

fr. - / srp. srce nekome vene za nekim

fr. - / srp. srce nekome kopni za nekim

- 'prestati misliti na nekoga/nešto', 'zaboraviti nekoga/nešto':

fr. - / srp. iščcupati nekoga/nešto iz srca

fr. - / srp. istrgnuti nekogalnešto iz srca

Najbrojniji su, međutim, frazemi u kojima se ističe povređenost osećanja neke osobe usled neprimerenog ponašanja druge (drugih) osobe (osoba):

- 'povrediti jako nekoga', 'rastužiti jako nekoga', 'potresti nekoga':

fr. briser le cœur de quelqu'un / srp. slomiti srce nekome

fr. arracher le cœur à quelqu'un / srp. ǐ̌čupati srce nekome

fr. déchirer le cœur à quelqu'un / srp. razdirati srce nekome

fr. fendre le cour à quelqu'un / srp. parati srce nekome

fr. blesser le cour à quelqu'un / srp. raniti nečije srce

fr. enfoncer un couteau, un poignard dans le cour de quelqu'un / srp. zariti nekome nož u srce

fr. plonger un couteau, un poignard dans le cour de quelqu'un (*zaroniti nož u srce nečije) / srp. -

fr. crever le cour à quelqu'un (*probiti srce nekome) / srp. -

fr. percer le cœur à quelqu'un (*probosti srce nekome) / srp. -

fr. - / srp. ujesti nekoga za srce

- 'povrediti jako nekoga', 'izaz(i)vati tugu', 'izaz(i)vati saosećanje':

fr. faire mal au cour (*praviti bol u srcu) / srp. -

U narednim frazemima uočavamo različita ponašanja čoveka koja ne odišu pozitivnom konotacijom:

- ' $\quad$ pomagati nezahvalnoj osobi koja će uzvratiti zlom':

fr. - / srp. hraniti guju na srcu

fr. - / srp. čuvati guju na srcu

fr. - / srp. nositi guju na srcu 
- $\quad$ 'ponašati se kao zavodnik', ‘biti Don Žuan’:

fr. faire le joli cour (*praviti lepo srce) / srp. -

fr. être un bourreau des cours (*biti dželat srca) / srp. -

- ' 'biti preterano ljubazan', 'ponašati se izveštačeno':

fr. faire la bouche en cœur (*praviti usta u srce) / srp. -

- $\quad$ 'ljutiti se, vređati se za sitnicu':

fr. - / srp. biti nakraj srca

4. Konceptualno polje 'način čovekovog delanja'

U ovo konceptualno polje uvrstile smo frazeme koji ukazuju na načine na koje čovek obavlja raznolike aktivnosti:

- ' 'mirno', 'lako', ‘bez oklevanja':

fr. le cour léger / srp. laka srca

fr. d'un cœur léger / srp. lakog srca

fr. - / srp. mirnog, mirna srca

- ' 'učiti napamet', 'znati napamet':

fr. apprendre, réciter, savoir par cœur (*naučiti, recitovati, znati na srce) / srp. -

- ' iskreno se poveravati jedno drugom':

fr. coeur à cœur (*srce srcu) / srp. -

$$
\text { - } \quad \text { 'iskreno', 'rado': }
$$

fr. $d u$ fond du coeur / srp. iz dubine srca

fr. à coeur ouvert / srp. otvorenog srca

fr. de tout (mon) cour / srp. iz, od sveg srca

fr. de bon cour (*iz srca dobrog) / srp. -

fr. de gaité de cour (*iz radosti srca) / srp. -

- ' 'otvoreno, iskreno govoreći':

fr. droit au cœur (*direktno u srce) / srp. -

fr. - / srp. ruku na srce

- $\quad$ 'sa pregršt emocija':

fr. cœur battant (*srce lupajući) / srp. - 
- 'sa entuzijazmom':

fr. de grand cour (*iz velikog srca) / srp. -

- 'protiv volje':

fr. à contre-cour (*protiv-srca) / srp. -

fr. - / srp. preko srca

fr. - / srp. teška srca

- 'sa tugom':

fr. le cour gros (*srca velikog) / srp. -

fr. - / srp. žalosna srca

- 'potajno':

fr. - / srp. $u$ dnu srca

- 'u izobilju', 'do mile volje':

fr. - / srp. koliko ti srce želi (jesti, piti)

- 'na prazan želudac', 'natašte':

fr. - / srp. našte srca (jesti, piti)

fr. - / srp. na gladno srce (jesti, piti)

Leksema srce u ovim potonjim primerima ima značenje ,želudac”, „stomak”. U tradicionalnoj lingvistici ove dve lekseme su etimološki povezane i smatraju se ‘okamenjenim' metaforama. U savremenoj jezičkoj praksi srpski izrazi ne sme se popiti prazna srca/na prazno srce i nosi dete pod srcem su zastareli.

5. Konceptualno polje 'središte'

U frazemima koji slede srce označava 'središte' u najširem smislu:

- $\quad$ središnje mesto (države, pokrajine, oblasti, kakvog prostora), središte, centar:

fr. être au cour de la ville / srp. biti u srcu grada

- $\quad$ vremenski posmatrano:

fr. être au cour de l'été (*biti u srcu leta) / srp. -

fr. au cour de la vie humaine (*u srcu ljudskog života) / srp. -

- $\quad$ suština, srž:

fr. entrer au cour des choses (*ući u srce stvari) / srp. - 
fr. toucher au cœur même de quelque chose (*dirnuti u srce nečega) / srp. fr. aller droit au cour de quelque chose (*ići pravo u srce nečega) / srp.-

- $\quad$ središnji deo razgovora:

fr. être au cœur du sujet, d'une question (*biti u srcu teme, pitanja) / srp. fr. toucher le cœur du sujet, d'une question (*dotaći srce teme, pitanja) / srp. $-$

- $\quad$ osoba koja ima glavnu ulogu u nekoj grupi, aktivnosti:

fr. être le cour d'une équipe / srp. biti srce ekipe

\section{ZAKLJUČAK}

Naša analiza izvršena je na korpusu koji čini 266 frazema, i to 156 francuskih i 110 srpskih. Na osnovu istraživanja možemo da zaključimo da je u frazeološkom izražavanju francuska leksema cœur produktivnija negoli srpska leksema srce, te da nudi raznovrsnije semantičke sadržaje i stilske nijanse za koje u srpskom jeziku ne postoje odgovarajući ekvivalenti. Leksičko i semantičko poklapanje u posmatranim jezicima uočili smo u 57 slučajeva, dok bezekvivalentnih frazema u francuskom ima 99, a u srpskom 53.

Definisale smo pet konceptualnih polja: 1) 'čovekove osobine', 2) 'čovekova stanja', 3) 'čovekov odnos prema drugim ljudima i svetu oko sebe', 4) 'način čovekovog delanja', 5) 'središte' i utvrdile da frazemi u našem korpusu prevashodno oslikavaju čovekove karakterne osobine, njegovo psihičko stanje i odnos prema drugim ljudima i svetu koji ga okružuje. U brojnim frazemima ističu se kako dobre karakterne osobine (dobrota, plemenitost, čistota duše, nežnost, iskrenost, spontanost, naivnost, radost, neustrašivost), tako i one loše (neosetljivost, zloba, plašljivost, okrutnost, nestalnost). Veliki broj frazema iskazuje neprijatna čovekova psihička stanja, prvenstveno tugu, povređenost, očaj, potom strah, bes, neraspoloženje, teskobu. Veoma je zanimljivo da u skupini frazema koji se odnose na čovekovo fiziološko stanje pronalazimo isključivo francuske frazeme budući da u njima leksema cœur zapravo upućuje na želudac i stomak, dok je ovakva upotreba u srpskom zastarela. S druge strane, o sreći i radosti svedoče samo srpski frazemi. Svega nekoliko frazema upućuje na radosno psihičko stanje što je svakako neobično budući da se pojam srce obično asocijativno povezuje sa nečim prijatnim i lepim.

Činjenica da u francuskom i srpskom jeziku pronalazimo znatno više globalnih frazema ukazuje na to da se osnovno značenje leksema fr. cœur / srp. srce iznimno retko koristi, te da je metaforična i metonimijska upotreba ovih leksema 
znatno češća $\mathrm{i}$ da one prevashodno označavaju i opisuju raznolika emocionalna stanja i psihološke karakteristike. Kod većine posmatranih frazema pozadinska slika je lako uočljiva i razumljiva. Isticanjem i opisivanjem čovekovih karakteristika $\mathrm{i}$ osećanja putem frazema umesto glagolima istovetne semantike ostvaruje se izuzetna ekspresivnost kakvu nefrazeološki izrazi i jezički spojevi ne mogu da iznedre.

Posmatrani francuski i srpski frazeologizmi utemeljeni na metaforičkim i metonimijskim preslikavanjima ukazuju na određene sličnosti u naivnoj slici sveta, mada nisu zanemarive ni izvesne raznolikosti budući da su dve lingvokulturološke zajednice bile izložene neistovetnim kulturološkim, istorijskim i drugim činiocima koji su uticali na stvaranje osobenih sociolingvističkih miljea.

\section{Dragana Drobnjak}

Snežana Gudurić

\section{HEART IN FRENCH AND SERBIAN PHRASEOLOGY}

\section{Summary}

This paper deals with French and Serbian phrasemes with the components Fr. coeur /Serb. Srce (heart). All the phrasemes were classified into five conceptual fields according to their underlying imagery and analyzed using semantic and contrastive analysis. In both languages, numerous examples emphasize a person's positive character traits (goodness, nobility, purity of soul, tenderness, sincerity, spontaneity, naivety, joy, fearlessness) as well as negative traits (insensitivity, malice, shyness, cruelty, inconsistency). A large number of phrasemes express a sad person's psychological states: primarily sadness, pain and despair, as well as fear, rage, unhappiness, and distress. The conclusion drawn from the analyses is that, the French lexeme coeur is more productive than the Serbian srce in phraseological expression.

Keywords: heart, phraseme, French, Serbian.

\section{LITERATURA}

Burger, H., Buhofer, A., Sialm, A. (1982). Handbuch der Phraseologie. Berlin/New York: Walter de Gruyter.

Guiraud, P. (1975). Les gros mots. Paris : Presse universitaire de France.

Guthrie, W. K. C. (1962). A History of Greek Philosophy, Vol. I, Cambridge: Cambridge University Press.

Moon, R. (1998). Fixed Expressions and Idioms in English. A Corpus-Based Approach. Oxford: Oxford University Press. 
Mršević-Radović, D. (1987). Frazeološke glagolsko-imeničke sintagme u savremenom srpskohrvatskom jeziku. Beograd: Filološki fakultet.

Radenković, Lj. (1991). Die Symbolik des menschlichen Körpers in der südslavischen ZauberspruchTradition. In: Körper, Essen und Trinken im Kulturverständnis der Balkanvölker. Berlin: Sonderdruck, 183-193.

Zybatow, L. (1997). Idiome und Parömien aus kognitivlinguistischer und translationslinguistischer Sicht (am Beispiel des Russischen und Ukrainischen). U: Internationale Tendenzen der Syntaktik, Semantik und Pragmatik. Akten des 32. Linguistischen Kolloquiums in Kassel 1997 (Hrsg. O. Spillmann / I. Warnke), Peter Lang - Europäischer Verlag der Wissenschaften, str. 579-588.

Apresjan, Ju. D. (1995). Izbrannye trudy. Tom II. Integral'noe opisanie jazyka i sistemnaja leksikografija. Moskva: Jazyki russkoj kul'tury. (Štampano na ćirilici!)

\section{IZVORI}

Drašković, V. (1990). Francusko-srpskohrvatski frazeološki rečnik. Beograd: Zavod za udžbenike i nastavna sredstva.

Le nouveau Petit Robert, Dictionnaire alphabétique et analogique de la langue française (2005). Paris: Robert.

Milosavljević, B. (1994). Srpsko-francuski rečnik idioma i izreka. Beograd: Srpska književna zadruga.

Rey, A. (2000). Le Robert, Dictionnaire historique de la langue française. Paris : Dictionnaire Le Robert.

Trésor de la langue française : dictionnaire de la langue du XIX et du XX siècle (1971-1994). Paris, Éd. du Centre national de la recherche scientifique: Klincksieck: Gallimard.

RMS 1.: Rečnik srpskoga jezika (2007). Novi Sad: Matica srpska.

RMS 6.: Rečnik srpskohrvatskog književnog jezika I-VI (1967-1976). Novi Sad (Zagreb): Matica srpska (- Matica hrvatska). 